\title{
Gender role and Decision-Making Power of Sahariya Tribe's Women in Lalitpur District, Uttar Pradesh
}

\author{
*Anjana Singh Rajpoot \\ Centre for the Study of Social Exclusion and Inclusive Policy, Jawaharlal Nehru University, New Delhi 110067
}

\begin{abstract}
The Sahariya tribe of the Bundelkhand region is considered one of the most backward, side-lined, and vulnerable tribes in the country. The present paper investigates the gender role of Sabariya women in terms of their participation in the decision-making process and simultaneously elaborates their socio-economic and sociocultural status. The major findings state that Sahariya women are relatively more active in the community than their male counterparts. Despite sharing the dual burden, the study revealed that the autonomy and decision-making power was confined to minor household issues only.
\end{abstract}

Keywords: Sahariya women, Decision making, Inclusion, Empowerment

\section{Article Publication}

䁪 Published Online: 15-Dec-2021

*Author's Correspondence

8 Anjana Singh Rajpoot

9 Centre for the Study of Social Exclusion and Inclusive Policy, Jawaharlal Nehru University, New Delhi 110067

$\triangle$ anju.anjana88[at]gmail.com

C 2021The Authors. Published by RESEARCH REVIEW International Journal of Multidisciplinary. This is an open access article under the CC BY-

NC-ND license

(https://creativecommons.org/licenses/ by-nc-nd/4.0/)

\section{Introduction}

Pandit Jawaharlal Nehru had given a Brief statement that "when a woman moves forward, then the entire family and village moves forward, and when the village moves then the entire nation moves." From Hindu mythology to India's struggle for independence to be the fastest-growing economy globally, women have played a powerful and decisive role in shaping narratives across capacities. Women make up $40.04 \%$ of India's population yet are considered marginalized, poorer, and deprived than men (Census, 2011). They face inequality in terms of basic needs and rights. According to WHO Status of women is generally measured using three indicators: - education, employment, and intra- household decision-making power (WHO, 1989). and these three indicators are the primary areas where women are discriminated against or unequal to their male counterparts. Sahariya tribe is also not free from gender inequality. Their community is patriarchal also the literacy rate among women is lower than the men. Also, they are poorer in their health condition. Women of the Sahariya tribe are working hard in the household as well as outside the home. They more participate as a marginal worker than the primary worker. Although Government and NGOs bestow various programs to reduce the gap between gender inequalities in society. But the Sahariya tribe women are still far behind in almost all the standard parameters of development. So, it is imperative to progress the tribal women in every field for the nation's development. It is also true that the whole story of any country would be conceivable only when women appraise as equal to men.

Sahariya tribe is the only tribe that resided in the Lalitpur district (Bundelkhand region), with a population comprising a Sahariya population of 23,644 (Census, 2011). The section has been historically mentioned in the holy scriptures of Hinduism, e.g., Yagya Puran, Vishnu Puran, and Varah Puran, which are the world's oldest scriptures and mentioned in Ramayana Mahabharata. The district is famous for its drought and hungriness. Lack 
of water and food is the main problem of people living in this area. People hardly get two times meal in a day. Economic growth and employment in gainful activities are the primary sources of healthy life of people. Still, a more significant extent of financial deficiency and unemployment became the root cause of this problem. Because of this, people have to work in mines and engage with labor work.

The villages of Lalitpur district have considered for the study are selected voluntarily with the consult of geographical and district officers, where the Sahariya population is resided inaccurate numbers according to the study requirement. Sahariya tribe is considered for the study because it is the only tribe that lives in this district with such poor conditions due to their isolation and remoteness. Another reason for selecting this area is that the Lalitpur district comes under the Bundelkhand region, divided into 7 Uttar Pradesh and 6 Madhya Pradesh districts. Lalitpur district is in the adjacent area of both states but comes into Uttar Pradesh. So, the development seems less than any other district.

Furthermore, Sahariya of Lalitpur District was the tribe designated as Scheduled Tribes group in 2003 (Registrar General of India, 2011). Till 2003, they were designated as Scheduled Caste. UP consists of $0.1 \%$ of the Sahariya tribe population, and Lalitpur (Bundelkhand region) is the only district where the Sahariya population resides.

Table .1 District Profile

\begin{tabular}{|l|l|l|}
\hline & Lalitpur & Uttar Pradesh \\
\hline Total Population & 1221592 & $199,812,341$ \\
\hline Rural Population & 1046214 & $155,317,278$ \\
\hline Number of District & 1 & 71 \\
\hline Number of Sub District (Tehsil/ Taluka etc.) & 5 & 312 \\
\hline Number of Villages & 752 & 106774 \\
\hline Sex Ratio & 906 & 912 \\
\hline Child Sex Ratio (0-6) age group & 916 & 902 \\
\hline Scheduled Caste Population & 240,519 & $41,357,608$ \\
\hline Scheduled Tribe Population & 71,610 & $1,134,273$ \\
\hline Literate Scheduled Caste & 114,962 & $20,948,471$ \\
\hline Literate Scheduled Tribe & 16,705 & 516,553 \\
\hline Total Literacy rate (\%) & 63.52 & 67.68 \\
\hline Male Literacy rate (\%) & 74.98 & 77.28 \\
\hline Female Literacy rate (\%) & 50.84 & 57.18 \\
\hline
\end{tabular}

Source: Census 2011, District Profile Lalitpur, Uttar Pradesh

Several studies have appraised women's decision-making power in the general context, many studies done on tribal communities. Still, very few specific studies have been done on the decision-making role among tribal women. Also, there is no particular study related to the Sahariya tribe in the Lalitpur district.

The population of the Sahariya tribe is about three lakhs, distributed over the districts of Morena, Shivpuri, Guna, Gwalior, and Vidisha of Madhya Pradesh and Baran district of Rajasthan, and a small number of Sahariya tribes comes in the State of Uttar Pradesh. They are being called by different names, viz. Sour, Sonr, Sahariya, Seharia, Soria, Sor and Rawat in Bundelkhand (Mandal, 1998). The Sahariya of the eastern belt prefers to use the suffix 'Rawat' as their surname instead of Sahariya. The women are referred to as 'Seharni.' However, in the 1881 census, the Sahariya appeared as 'Aboriginals,' 'Animist' in 1901, 1911, and 1921, a 'tribal' (Crooke, 1896). When we talk about the etymological meaning of the word Sahariya it originates from 2 words- "Sa" means companion and "Haria" means tiger, which together means companion of the tiger (Tiwari, 1984).

There are many myths about their origination. One of them is the ancestral lineage with the Sabri of the Ramayana, and the other propagates the theory of belonging to the creation by Brahma. However, there is no written record. The idea of Brahma suggests that Brahma, who is the creator of the universe, created people and placed them in a particular order. The Sahariya tribe was kept in the middle of the people he made. But when the 
creator started creating more people, these people joined the earlier created people and, in the long run, pushed the Sahariya to the other end, which ended him in the extreme corner.

Further, the myth talks about how furious Brahma, the creator, was when he saw the Sahariya at the end of the corner. He blamed the Sahariya for the inability to cope with such external pressure and therefore punished him by making him live in the forest or places on the outskirts. Another theory claims them to be the descendant of Baiju Bheel, a worshiper of the Hindu god Shiva (Vishwakarma, 2010). Now when asked about their history, the older generation cannot recollect the generational history of their tribe. They could only trace until their grandfather.

Sahariya tribe is poor, ignorant, and highly backward, with a lower literacy rate. Their main livelihood is labor work and agriculture. Forest collection, hunting, fishing, and livestock rearing are their other sources of livelihood. They live near hills and valleys. There is some impact on their traditional way of life due to some developmental programs, but they remained backward compared to the civil society. Sahariya women, on the other hand, face a different kind of inequality in terms of their decision-making power and role. They do participate in economic activities with males yet do not consist a powerful position in the household and society.

So, this paper investigates the level of empowerment among Sahariya women in terms of their participation in decision-making process and simultaneously elaborates their socio-economic and socio-cultural status of their decision-making role. They have also identified whether the Sahariya women have the same status as rights regarding equality, education, health, labor, employment, marriage, and family life. So, the study gave substance to focus the areas as mentioned above of Lalitpur district.

\section{Review of Literature}

From independence to the contemporary era, the development in India has served to widen the opportunities for different groups of women. Nowadays, these women have greater access to education and employment and can participate in the economy on an equal basis with men (Karlekar 1982; Liddle \& Joshi 1986). However, generalizing these privileges to the more prominent female population is quite misleading. A more significant number of female folks in India are still suffering from impoverishment. Estimates suggest that more than 70 percent of the women in India live at or below a minimum subsistence level (Mukhopadhyay, 1984). The most extreme deprivation finds among Scheduled caste and scheduled tribe women and groups designated as PVTG in Indian Constitution. The status of these women from minority groups mixed with India's patriarchal culture to produce deplorable living conditions (Ghandially, 1988). These 'doubly disadvantaged' women strive not for gender equality but their very survival (Mukhopadhyay, 1984). The Dhebar Commission Report (1961) describe that the tribal women are not drudge or a beast of burden, she is found to be exercising a relatively free and firm hand in all aspects related to her social life. The tribal women in general and in comparison, with castes, enjoy more freedom in various walks of life. Traditional and customary tribal norms are comparatively more liberal to women. But the view point of others proposes that tribal women are generally a suppressed group. When the question of exclusion arises, we can say tribal women are always excluded from the employment opportunities and benefits from the development projects etc (Majumdar and Madan,1986). They share abundant responsibilities and perform multiple duties in running the family and maintaining the household, attending to farm labour, tending domestic animals and poultry birds. And, after fulfilling all these activities, she is an unpaid servant to man whose labour is never measured in economic terms (Bhasin, 2007). Despite representing approximately half of the entire tribal population, women in tribal society are more imperative than other social groups. They work harder, and the whole responsibility of family economy and management relies upon her. Yet, they are not seeming to be very active in making significant decisions in terms of financial and health-related. Their role is limited to contribute to household chores, raising kids, and agriculture or labor work only. There are studies related to tribal women in which this can be described thoroughly. 
Elwin (1969) describes in his study on Santhal, Ho, and Munda society those tribal women are primarily identified with other women in terms of the equivalent situation, adore uncertainties, and a similar commitment to her home, to husband, and children. He also tried to locate their roles and position out there. Any type of hierarchical structure is non-existent in his study area. He also found that the societies in which he studied are 'classless and 'casteless and more or less run by a democratic scheme. A palpable sense of egalitarianism is noticed in community membership irrespective of sex. Being a patriarchal society, the father is the head of the family, and only male members of the house can become heirs to their ancestral belongings. No female can accede to the family's landed possessions.

Gogdand and Hembade (2014) said in their study that no woman could decide without their husband's permission for selling the animals. Also, for the consumption of milk at home taken care of by the husband, women cannot make their own decisions.

In her study, P.V Sumitha (2016) reveals that women strengthening is a worldwide issue fascinating the consideration of specialists. Strengthening is a term widely utilized as a part of the setting of women who are equal partners being developed by the general public and the country.

Das (2012) described a case study for the socio-economic empowerment of tribal women in India. His study illustrates different social, economic, political, physiological, and technological restraints regarding the empowerment of tribal women. he also attempted to analyse the limitations in women in the tribal regions of Assam state. His research depicted that cognitive and infrastructural constrictions are chief obstacles for tribal enlargement as well. Specifically, he described that the major causes for the meagre empowerment of tribal women were documented as a lack of knowledge and awareness regarding the latest technology and information.

\section{Objective}

- To examine the Decision-making role of the Sahariya tribe's women.

- To explore the extent to which the decision-making role of tribal women is affected by their socioeconomic and socio-cultural status.

\section{Methodology}

The study is based on both qualitative and quantitative using primary data. The method used for the study would be the Quasi-Participant method. It is a mixture of Participant and Non-participant observation. This method would be used to understand them through an insider as well as an outsider's point of view. The level of empowerment among Sahariya women in terms of their participation in the decision-making process simultaneously elaborates their decision-making role's socio-economic and socio-cultural status. Interview schedule, focus group discussion and field notes are using to conduct the field survey.

\section{Area of the Study}

The research will be carried out in two different villages (Mainwara and Baswna) of Lalitpur district, where the Sahariya population lives in subsequent numbers. While selecting the villages, attention was given to select backward villages having a considerable tribal population. Selected villages are in the range of $40 \mathrm{~km}$. from the district area with a population of 2000-3000 approximately. The unit of the study is ever-married women in one household.

\section{Sample Size}

The research area comprises two villages with a population of 2000-3000, of which this research includes 80 households for the study. Sample sizes 80 have been taken using the Purposive sampling technique, which is stratified in 2 villages according to the proportion of the Sahariya people. 
Major Findings

Table .1: Age of the Respondents

\begin{tabular}{|l|l|l|}
\hline Age & Number & Percentage \\
\hline $15-24$ & 18 & 22.5 \\
\hline $25-34$ & 35 & 43.7 \\
\hline $35-44$ & 14 & 17.5 \\
\hline Above 45 & 13 & 16.3 \\
\hline Total & 80 & 100 \\
\hline \multicolumn{2}{|c|}{ Source: Survey data } \\
\hline
\end{tabular}

Source: Survey data

The present study found that the age category of respondent's 43.7 percent belongs to 25-34 years of age group, and a minimum of 16.2 percent belongs to above 45 years of age group.

Table .2: Marital Status of the Respondents

\begin{tabular}{|l|l|l|l|}
\hline S. No. & Marital status & No. of Respondents & Percentage \\
\hline 1. & Married & 66 & 82.6 \\
\hline 3. & Divorced & 0 & 0 \\
\hline 4. & Separated & 3 & 3.7 \\
\hline 5. & Widowed & 11 & 13.7 \\
\hline & Total & 80 & 100 \\
\hline \multicolumn{4}{|r}{ Survey Data }
\end{tabular}

The marital status reveals that the majority 82.6 percent of respondents have been married. 13.7 percent of women are belonging to the widowed category and no women are divorced found in the study area, although 3.7 percent of women are separated.

Table .3 Age at Marriage

\begin{tabular}{|l|l|l|}
\hline Age at Marriage & No. of Women & Percentage \\
\hline Before 10 & 2 & 2.5 \\
\hline $10-14$ & 25 & 31.3 \\
\hline $15-19$ & 43 & 53.7 \\
\hline $20-24$ & 8 & 10 \\
\hline After 25 & 2 & 2.5 \\
\hline Total & $80 \quad 100$ \\
\hline \multicolumn{2}{|c|}{ Survey Data } \\
\hline
\end{tabular}

Age at marriage reveals that a significant 53.7 percent of women respondents had married at the age of 18 or below 18 years. Women are married earlier than men.

Table .4 Type of Families

\begin{tabular}{|l|l|l|l|}
\hline S. No. & Type of Families & No. of respondents & Percentage \\
\hline 1. & Joint & 28 & 35 \\
\hline 2. & Nuclear & 52 & 65 \\
\hline & Total & 80 & 100 \\
\hline \multicolumn{2}{|r|}{ Survey Data } \\
\hline
\end{tabular}

The type of family reveals that the majority 65 percent are belonging to the nuclear family and 35 percent belong to the joint family. Sahariya tribe has a higher percentage of the nuclear family, which shows that the Sahariya tribe has significantly influenced with modernization. 
Table .7 Family size of the Respondents

\begin{tabular}{|l|l|l|l|}
\hline S. No. & Ranges of Family Members & No. of respondents & Percentage \\
\hline 1. & Up to 5 & 6 & 7.5 \\
\hline 2. & 6 to 9 & 48 & 60 \\
\hline 3. & 10 and above & 26 & 32.5 \\
\hline & Total & 80 & 100 \\
\hline
\end{tabular}

Source: Survey Data

The study reveals that the majority 60 percent of families have 6-9 members in the house and only 7.5 percent of families having up to 5 members in the community.

Table. 8 Type of the House

\begin{tabular}{|l|l|l|l|}
\hline S. No. & Type of house & No. of respondents & Percentage \\
\hline 1. & Kuccha & 28 & 35 \\
\hline 2. & Puccha & 7 & 8.7 \\
\hline 3. & Khaprel & 45 & 56.3 \\
\hline & Total & 80 & 100 \\
\hline
\end{tabular}

Source: Survey Data

Type of house reveals that majority of respondents 56.3 percent have lived in khaprel house and 35 percent lived in kaccha house. And rest live in the one-room pukka house provided by the government.

Table .9 Latrine Facility

\begin{tabular}{|l|l|l|l|}
\hline S. No. & Latrine Facility & No. of Respondents & Percentage \\
\hline 1. & Yes & 49 & 61.2 \\
\hline 2. & No & 31 & 38.8 \\
\hline & Total & 80 & 100 \\
\hline
\end{tabular}

In the case of latrine facility maximum, 61.2 percent case reported that they have the latrine in their house but they do not use it. they use the latrine to store their firewood or graze. Also due to lack of water and proper tank system, they are more like to open defecation.

Table .9 Educational Status of the Respondents

\begin{tabular}{|l|l|l|l|}
\hline S. No. & Literacy Status & No. of Respondents & Percentage \\
\hline 1. & Illiterate & 52 & 65 \\
\hline 2. & Just know the Signature & 22 & 27.5 \\
\hline 3. & Literate & 6 & 7.5 \\
\hline & Total & 80 & 100 \\
\hline
\end{tabular}

Source: Survey Data

The educational qualification of the respondent indicates that a maximum of 65.5 percent is illiterate and 27 percent of respondents just know the signature and only 7.5 percent of the respondent are belonging to the literate category. The education backwardness is prevalent in the Sahariya community, especially among the Sahariya women. They said it is due to economic problems and lack of parent's interest and household work.

Table .10 Work participation engagement of the respondents

\begin{tabular}{|l|l|l|l|}
\hline S. No. & Work participation engagements & No. of respondents & Percentage \\
\hline 1. & Household activities & 66 & 82.5 \\
\hline 2. & Work outside of home (Paid as a laborer) with household activities & 14 & 17.5 \\
\hline 3. & Total & 80 & 100 \\
\hline
\end{tabular}

Source: Survey data 
Work participation engagement reveals that a maximum of 82.5 percent of respondents engaged in work outside the home. And 17.5 percent of respondents maintain only household activities. The respondent said, they mostly engage in paid daily wage worker activities. They have to work mostly 7 days a week and 5 to 9 hours a day.

Table .11 Participation in the land ownership activities

\begin{tabular}{|l|l|l|l|}
\hline S. No. & Participation in the land ownership activities & No. of Respondents & Percentage \\
\hline 1. & Yes & 15 & 18.8 \\
\hline 2. & No & 65 & 81.2 \\
\hline & & 80 & 100 \\
\hline
\end{tabular}

Source: Survey Data

The majority 81.2 percent of respondents have said that they do not participate in the land ownership activities or related ones they don't know about. 18.8 percent of respondents do know about their property and they have ownership in their property too.

Table. 12 Children's future decision making

\begin{tabular}{|l|l|l|l|}
\hline S. No. & Role of women in Decision making for their children & No. of Respondents & Percentage \\
\hline 1. & Mother & 13 & 16.2 \\
\hline 2. & Father & 57 & 71.2 \\
\hline 3. & Other (grandparents) & 10 & 12.6 \\
\hline & Total & 80 & 100 \\
\hline
\end{tabular}

Source: Survey data

The study on deciding for the future of children has been found that, in majority 71.2 percent of the cases, fathers take the decisions regarding their children's future. Whereas in 16.2 percent cases female member decide for their children and rest 12.6 percent cases the future of the children is decided by the grandparents of the family that too is the male member or head of the family. Female does not have any role to decide anything for their children, their responsibility is limited with raising their children and socialize them. decisions regarding their education, marriage, work everything is handled by the male member or head of the family. Sometimes, both spouses take the decision, but the final decision is taken by the male member of the family. So ultimately, the final decision is made by their head/ male member of the family.

Table .13 Role of women in Family planning decision making

\begin{tabular}{|l|l|l|l|}
\hline S. No. & Family planning & No. of respondents & Percentage \\
\hline 1. & Yes & 28 & 35 \\
\hline 2. & No & 52 & 65 \\
\hline & Total & 80 & 100 \\
\hline
\end{tabular}

Source: Survey data

In the majority, 65 percent of family planning decisions are taken care of by the husband. Women do not have any say whether she wants children or not. Whereas 35 percent of respondents say they both decide for the family planning, a husband is the owner of the decision.

Table .14 Role of women in Purchasing and selling goods

\begin{tabular}{|l|l|l|l|}
\hline S. No. & Purchasing and selling goods & No. of Respondents & Percentage \\
\hline 1. & Yes & 26 & 32.5 \\
\hline 2. & No. & 54 & 67.5 \\
\hline & Total & 80 & 100 \\
\hline
\end{tabular}

Source: Survey Data 
The study reveals that purchasing or selling any good/item majorly 67.5 percent is decided by the male member of the family. He decides what and where to sell the goods and what amount. Only 32.5 percent of respondents said they actively participate in the selling and purchasing any goods.

Table.15 Most common diseases suffered by Respondents

\begin{tabular}{|l|l|l|l|}
\hline S. No. & Diseases & No. of respondents & Percentage \\
\hline 1. & Skin disease & 8 & 10.0 \\
\hline 2. & Diarrhea and Dysentery & 23 & 28.8 \\
\hline 3. & Fever & 17 & 21.2 \\
\hline 4. & Stomach disorder & 12 & 15 \\
\hline 5. & Cough and cold & 9 & 11.2 \\
\hline 6. & Body pain & 11 & 13.8 \\
\hline & Total & 80 & 100 \\
\hline
\end{tabular}

Source: Survey data

The study illustrates that females suffer more from acute diseases than males within six months. Females suffered more from skin diseases $(10 \%)$ followed by diarrhea and Dysentery $(28.8 \%)$, fever $(21.2 \%)$, stomach disorder $(15 \%)$, cough and cold $(11.2 \%)$, and body pain $(13.8 \%)$.

Table .16 Preference of the treatment

\begin{tabular}{|l|l|l|l|}
\hline S. No. & Preference of treatment & No. of Respondents & Percentage \\
\hline 1. & Government hospitals & 13 & 16.2 \\
\hline 2. & Traditional health healer & 59 & 73.8 \\
\hline 3. & Private hospitals/Local clinics & 8 & 10 \\
\hline & Total & 80 & 100 \\
\hline
\end{tabular}

Source: Survey Data

The majority of respondents 73.8 percent preferred traditional medicine or local health healer over modern medicine to cure their acute diseases, 16.2 percent went to Government hospitals in emergency cases. Sahariya tribe has blind faith in their religious deities. Which negatively affected their health.

Table .17 Health-related decisions

\begin{tabular}{|l|l|l|l|}
\hline S. No. & Health-related decisions & No. of Respondents & Percentage \\
\hline 1. & Female & 21 & 26.2 \\
\hline 2. & Male & 59 & 73.8 \\
\hline & Total & 80 & 100 \\
\hline
\end{tabular}

Source: Survey Data

The study reveals that the health-related decisions are majorly 73.8 percent taken care of by the male member of the community. 26.2 percent of decisions are headed by female members of the community.

Table 18 Decision making in the socialization process of the children

\begin{tabular}{|l|l|l|l|}
\hline S. No. & Socialization process & No. of respondents & Percentage \\
\hline 1. & Female & 62 & 77.5 \\
\hline 2. & Male (Both) & 18 & 22.5 \\
\hline & Total & 80 & 100 \\
\hline
\end{tabular}

Source: Survey data

The majority 77.5 percent of respondents reveal that in the socialization process of children their male member plays a minimum or negligible role, full responsibility is on the shoulder of the female member of the family. Whereas 22.5 percent respondent says they both handle the socialization process equally. 
Table. 19 Awareness towards government policies

\begin{tabular}{|l|l|l|l|}
\hline S. No. & Awareness towards government policies & No. of respondents & Percentage \\
\hline 1. & Yes & 27 & 33.7 \\
\hline 2. & No & 53 & 66.2 \\
\hline & Total & 80 & 100 \\
\hline
\end{tabular}

Source: Survey data

The majority 66.2 percent of respondents said they are not aware of the various Government schemes for the Sahariya tribe. 33.7 percent of women said they have little knowledge about the schemes running by the government. But they have no access and the reach and facilities to use the benefits of the Government schemes.

\section{Analysis of the Findings}

- Data shows that early marriage or child marriage directly or negatively affects a girl's educational attainment, which negatively impacts the girl's decision-making abilities. Thus, Sahariya women have a minor contribution to their family decisions.

- Findings reveal that literate Sahariya women can actively participate in various decision-making activities with their male counterparts.

- Data shows that the Sahariya women who have engaged with the household activities have a minimum or minor role in the decision making rather than the women who have engaged in skillset activities and labor work. However, skillset activities increase their role in decision-making power more than wage labor work.

- Due to unawareness of various health and family planning measures, they have a minimum role in the decision-making of family planning matters.

- All the respondents from the villages are reported that they share their property with their son but not with their daughter.

- The differences in workplace have also seemed among them, for example, digging the pond, cutting woods, constructing building and roads, lifting heavy goods, etc. are done by men whereas sand, cement, soil, lifting light goods done by women worker.

- Findings reveal that the patriarchal form of decision-making and dominance over women could now allow Sahariya women to enjoy their autonomy in various places. Socialization process of children, healthrelated decisions, land-related matters, purchasing and selling of goods, etc.

The findings have suggested that in the majority of cases the major decisions are taken by the male member of the society whereas women have to maintain all the household, children and outside work yet they don't have the right to make decisions. The reason behind this is patriarchy and the influence of Hindu culture. As in the study area Sahariya lives amongst the Hindu society so they have influenced with them. In general, tribes are considered as an egalitarian society where women hold a position there and can make major decisions but in the Sahariya tribe, the male member is in more power in terms of decision making.

\section{Contribution of Sahariya tribe's women in different areas.}

Sahariya women vigorously partake in every bubble of economic activities and contribute to the household economy in a momentous way. They provide not just help but equal contribution along with their male counterpart. Even though they are mostly uneducated, they have the proclivity to accumulate in terms of cash/or kind for the future. Sahariya women engaged also engage in the business of collecting medicine and woods from the forest and sell them to the nearby market also engage in the liquor doing work. In the field area, this has been also found that some women consume liquor to get rid of their labor pain during pregnancy. After all, these economic activities majority of the Sahariya women have a very less part of the contribution in the decisionmaking process related to expenditure and other economic activities. 
Sahariya women from diverse groups chip in agricultural deeds as helping hand with their family members. The agricultural activities can be divided into pre-harvesting, post-harvesting, and harvesting activities where Sahariya women contribute differently. Pre-harvesting operations include selecting seeds, applying fertilizers, repairing irrigation channels, sowing of seeds, uprooting and transplanting seedlings, weeding application of pesticides, insecticides, irrigation, and guarding, which consume 5-6 hours per day. Pre- harvesting operations are majorly accomplished by male folk accompanied by women. Further, the post-harvesting activities, including thrashing, winnowing, and drying of grains, storage, and transportation, are mainly done by women of the community. during fieldwork, this could be seen that Sahariya women done most of the work in the field from loading cow dung to the field for levelling the soil and finally transplanting the seedlings and weed the field every day all along the entire rainy season. Since the house of the Sahariya tribe in the village is observed to be present far away from the agricultural lands, the women laborers have to cover a long distance every day to reach the field. Apart from land farming, some houses of the Sahariya tribe are also engaged in vegetable production and the main responsibility comes to the women member of the household. In agricultural work, they play a major part.

\section{Wage labour:}

Sahariya women are significantly engaged in wage labor activities outside the village as well as inside the village. Their economy's most imperative and appealing fact is that they never follow one occupation exclusively. The male folk seasonal variation brings dynamism in work participation and contribution of Sahariya women. Sahariya women mostly work as mining wage labor, construction work, and agricultural labor outside the village. Sahariya women generally go in the tiny clusters and work under different contractors in these jobs.

\section{Livestock's/Poultry:}

Poultry production and livestock production is an important area marked by the vigorous participation of Sahariya women, where they play multiple roles and provide productive inputs in terms of working hours. Most of the households in the study area possess goats and buffalo and in very rare cases cows. An ample amount of time is reported to be spent by the women in the care of livestock activities.

\section{Household activities:}

Household activities consume the maximum time of Sahariya women these activities play an important role in their life. From cooking food to cleaning and nurturing children and task exterior to the home (gathering of firewood, fetching water, and farming work), everything is a sole responsibility to the women of the household. In the study area, Sahariya women shared that they are the first to get up and commence the day's job. For them, everyday life is rather a balancing act as they strive to assimilate a series of responsibilities and errands. Sahariya women mostly do not send their girl children to school so that they can help them in household chores and maintenance. Sahariya women limit their decision-making power in purely domestic matters like making Chulla for cooking food, purchasing domestic goods, managing all cooking-related activities, and nurturing their child. They also accomplish social and religious activities, including entertaining guests at home, visiting relatives, attending a marriage, and celebrating festivals with other Sahariya women. They enjoy their autonomy at this level and live happily. They do not have any complaints regarding their life or day-to-day activities.

\section{Conclusion}

To conclude this Paper, Sahariya women in the study do not enjoy a high degree of autonomy in decision-making despite their significant contribution to the various economic activities and other household works. Sahariya women have the freedom to make decisions in the domestic matters of cooking and nurturing children. But matters related to children's education and occupation and money-related matters have limited or no freedom. Due to engagement in various economic activities, they have the freedom to go outside, but they also have to inform their male partners. Patriarchy plays a significant role in forming the decision-making powers and its dominance over women continues in the study area. Due to living amongst the Hindu society, Sahariya inherits 
their culture and ways of living. Education and improvement in their economic independence will help in increasing Sahariya women's involvement in decision-making in the family.

\section{Suggestions and Policies}

Health, education and nourishment should be selected key focus areas, besides; women should be provided ample opportunities for economic development, based upon the traditional skills, women should also be provided additional skills for value additions to the produces

- More awareness of generation especially focuses on girl child (proper implementation of governmental schemes, educational awareness, and generation of new programs for giving employment to the poor) among the Sahariya tribe to abolish faith blindly and believe on God and make them economically sufficient so that they can actively participate in activities for their benefits and uplift their status.

- The political participation of Sahariya women in panchayat and other political activities is very low. Hence, the government should take the initiative for the political empowerment of the Sahariya tribe's women.

- Cultural conceptualization and folk explanation have a significant association with the sanitary condition, the system of medicine opted, and the medical care institution. So, to modernize the concepts regarding health and illness, recruit ASHA workers and Anganwadi workers from the Sahariya tribe community itself.

- Enhancement of their traditional and medicinal knowledge.

- Literary status among women of Sahariya tribe is very low with high dropout ratio. There is a significant association between literacy level and decision-making power. Education is a powerful tool to empower the Sahariya women and make them capable to equally participate in the household and economic activities. Education must be provided according to their cultural characteristics. So joint venture of tribal department and education department is needed.

- Stringent rules must be passed to ensure that corrupt practices do not hamper and harass the people of Sahariya tribe, they should be properly investigated in the situation without giving favour to anyone else.

- With the formulation of development policies, the main focus should be given on the implementation to create awareness and to inbuilt self-reliance among tribal females.

- Women should be provided with opportunities for leadership training.

- Priority must be given to timely monitoring the improvement in their status condition.

- Women empowerment does not signify increasing the numbers of women in decision making position. There should be measures to improve the quality of participation. The quality of participation signifies taking initiatives in new projects, identifying problems and providing suggestion towards effective solution.

\section{References}

Acharya, M. 1995. Women and the subsistence sector economic participation and household decision making in Nepal. Social welfare, Vol. 6.

Bala, M. and Monga, O.P. 2004. Impact of women employment on decision making in families. Social welfare, Vol. 51, pp. 13-16.

Banerjee, P. 2005. Rights and Representation: Debates over Women's Autonomy in India. Retrieved from: http://www.mcrg.ac.in. Assessed on 20 August, 2021.

Bullock, S. 1994. Women and Work: Women and World Development Series. London: Zed Books.

Das, K.S. 2012. Best Practises of Self-Help Groups and Women Empowerment: A Case of Barak Valley of Assam. Far East Journal of Psychology and Business, 7(3): 29-51. 
Das, M.S. 1993. Decision making practices of employed and non-employed home makers. Journal of north -east India council for social science research, Vol. 17, pp.46-78

Das, S. 2012. An Analysis of Constraints in Women Empowerment in Tribal Area: Evidences from Assam. Asian Journal of Research in Social Science and Humanities, Vol .2, ISSN 2249 7315, Retrieved from www.aijsh.org/setup/socialsciences/paper146.pdf, Assessed on 22 August 2021.

DFID, 2000. Poverty elimination and the empowerment of women. Strategies for achieving the international development target. Department for International Development, pp., 1-35.

Elwin, V. 1969. The Nagas in the 19th Century. Oxford University Press, Oxford.

Kalpagam, U. 1999. Women, Work and Domestic Duties: Income Planning for Housewives. Indian Journal of Labour Economics, 42(4): pp. 568-80.

Mitra, A. 2007. The status of women among the Schedule tribes in India. The Journal of Socio-economic.

Mitra, A. 2008. The Status of Women Among Scheduled Tribes in India. Journal of Socio-Economics, 37(3): pp. 12021217.

Mohd, A 2009. International journal or rural studies. Vol 16, ISSN1023-2001, Retrieved from http://www.ivcs.org.uk/IJRS Assessed on 18 August 2021.

Nath, D. C., Goswami, G. 1991. A Comparative analysis of status of women among the seven states of north India, pp. 65-74. Retrieved from http://mihfw.org/publication/materials/j274.pdf. Assessed on 18 August 2021.

Sethi, H. 1992. Gender and Tribe- Women, Land, and Forest in Jharkhand, India, Devnathan Publication, Retrieved from http://dx.doi.org/10.1016/j.wsif.2010.03.002. Assessed on 15 August 2021.

Sethi, R.M. 1998. Status and power of working women within the family, A test of Marxisan perspective. Journal of Sociological Studies, Vol 8: pp97-108.

Singh, A.K. and Garcia, P.S. 1999, Female work participation and involvement in decision making process: a study on Uttar Pradesh. Indian journal of agricultural economics. Vol. 50: pp. 300-301.

Soni, K. and Jindal, B.R. 1983. Effect of employment of women on family decision making patter. Journal of Research, pp 519-524.

Sudan, F.K. 2007. Livelihood diversification and women empowerment. Indus Journal of Management and Social Sciences, Vol. 1: pp 90-106. 